\title{
Anuran Diversity in Bhawal National Park, Gazipur, Bangladesh
}

Israt Jahan, Esika Paul, Ashim Mollik, Nigar Sultana, and Konok Roy

Wildlife and Nature Conservation Circle, Bangladesh Forest Department Ban Bhaban, Agargoan, Dhaka (israt.jebin@yahoo.com)

$\mathrm{A}_{\mathrm{p}}^{\mathrm{n}}$ mphibians are an essential component of ecosystems that provide services for human society (Hocking and Babbitt 2014). They occupy a great variety of climatic and ecological zones (Hall and Henry 1992). Unfortunately, they also are among the animals most threatened with extinction, largely due to negligence and anthropogenic issues (e.g., Stuart et al. 2008). A recent assessment (Stuart et al. 2004), based on the International Union for Conservation of Nature (IUCN) Red List, declared that $32 \%$ of the amphibians in the world are now seriously threatened.

Bangladesh is located at the junction of the IndoHimalayan and Indo-Chinese Subregions (Stanford 1991) and is part of the Indo-Burmese biodiversity hotspot (Myers et al. 2000). Hasan et al. (2014) recorded 71 species of amphibians from Bangladesh. Bhawal National Park (BNP), in central Bangladesh, was rich in biodiversity (Sarker and Fazlul Huq 1985) but much of the habitat in the park was converted into highly disturbed forest due to ongoing anthropogenic problems that followed the Liberation War of 1971 (Kabir and Ahmed 2005; Rahman and Vacik 2009; Hasan and Bahauddin 2014). The intent of this study was to survey the park for previously undocumented amphibian species and to provide new information to facilitate the development of future conservation priorities for park management.

\section{Study Area}

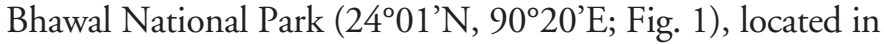
Gazipur District, $40 \mathrm{~km}$ north of the capital city of Dhaka, is managed by the Bangladesh Forest Department and comprises approximately 5,022 ha that include a 950-ha core area (Kabir and Ahmed 2005). The forested areas are honeycombed with habitations and rice fields. The topography is characterized by low berms that rise $3.0-4.5 \mathrm{~m}$ above the paddy fields (known locally as "chalas"), and these are intersected by numerous depressions or "baids." Sal (Shorea robusta), the dominant tree species, covers about $90 \%$ of the area (Kabir and Ahmed 2005). Approximately 297 ha of the total park area consist of various bodies of water (unpublished Bangladesh Forest Department data) that include a 6-km- long excavated lake and six ponds in the core area. Temporary pools, paddy fields, small patches of water, and wet grasslands provide additional amphibian habitats.

\section{Methods and Materials}

We conducted surveys during the monsoon season on rainy evenings and nights (and occasionally during daytime) of 15-17 August 2013, 8-10 August 2014, and 7-9 September 2015. We actively searched waterlogged areas, agricultural fields, shrubs and trees, and under rocks and logs or other ground debris to check for sheltering amphibians. We photographed all animals found using digital cameras (Canon power shot 50x HS and Nikon P 35). We used GPS (Garmin eTrex 30x) to record coordinates of each locality. To identify amphibians, we used descriptions and keys in Dubois (1975), Dutta and Manamendra-Arachchi (1996), Bossuyt and Dubois (2001), Chanda (2002), Das (2008), Ahmed et al. (2009), Kabir et al. (2009), and IUCN Bangladesh (2015). To identify three species of frogs in the genus Fejervarya ( $F$. nepalensis, F. pierrei, and F. moodiei), we relied on morphological descriptions in Borthakur et al. (2007), Kurniawan et al. (2011), Hasan et al. (2012), and Ahmed and Alam (2015). We used nomenclature from Frost (2015).

\section{Bufonidae}

\section{Results}

Asian Common Toad,

Duttaphrynus melanostictus (Fig. 2)

These toads are abundant in BNP. We frequently encountered them at night in grassy areas, leaf litter, on the forest floor, in agricultural plots, and in dark corners of human settlements.

\section{Dicroglossidae}

\section{Indian Bullfrog, Hoplobatrachus tigerinus (Fig. 3)}

Although not commonly encountered, we found these frogs in various habitats, including small ponds, lake, temporary bodies of water, and on the forest floor near water. Our observations differed from those of Kabir and Ahmed (2005), who found 


\section{Bhawal National Park}

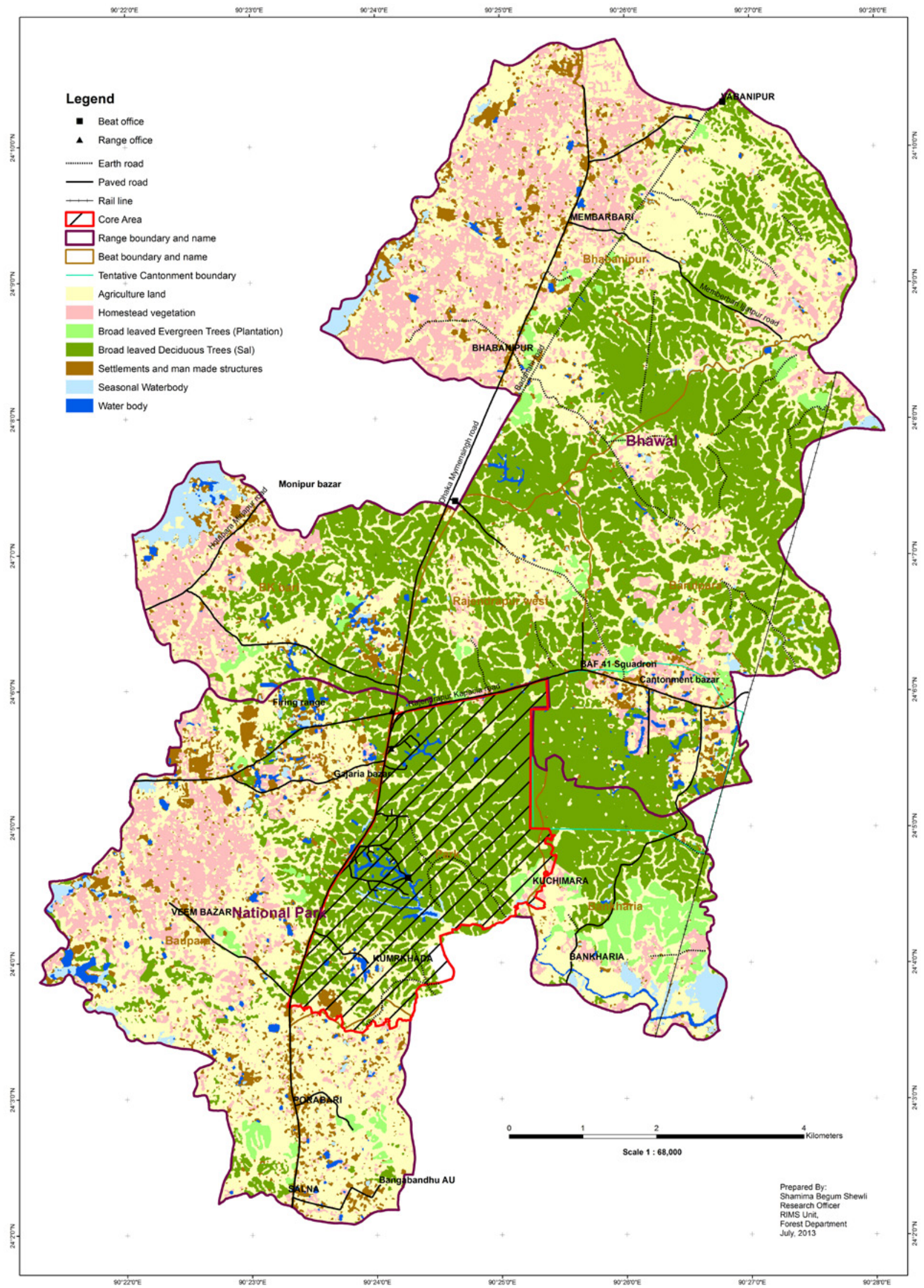

Fig. 1. Map of Bhawal National Park, Bangladesh. 


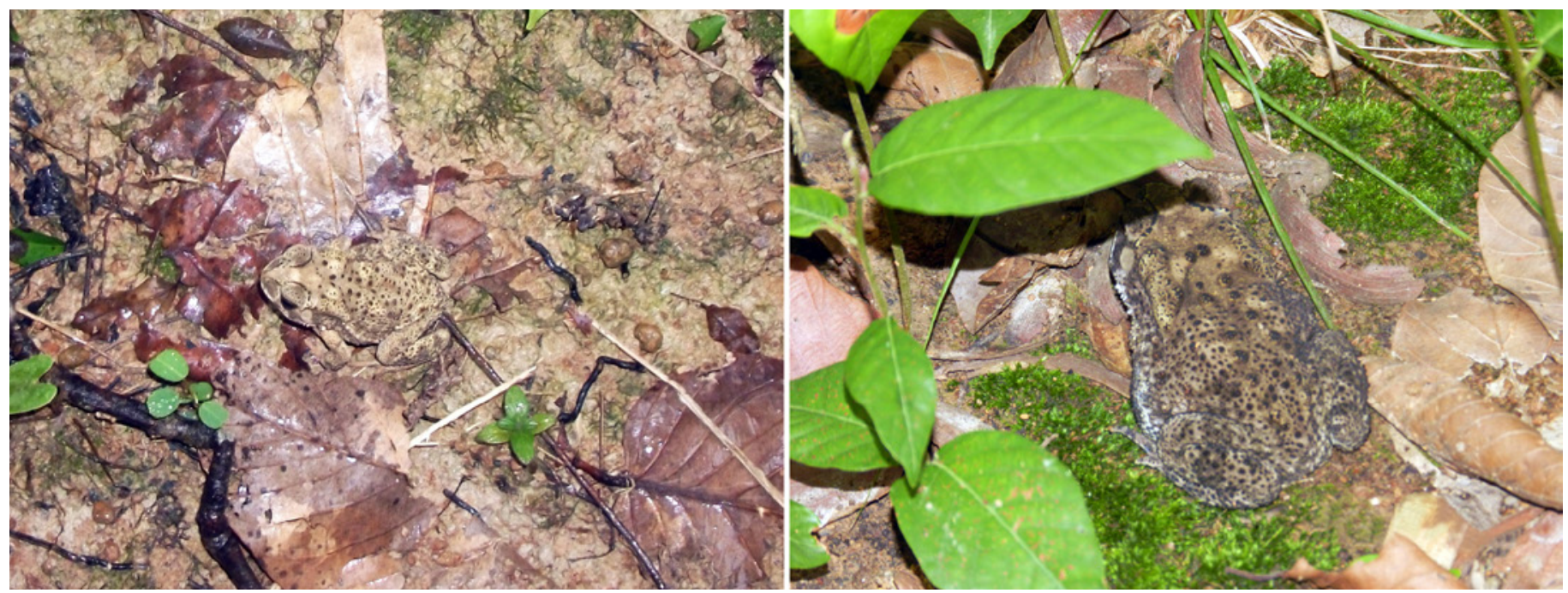

Fig. 2. Asian Common Toad (Duttaphrynus melanostictus). Photographs by Konok Roy.
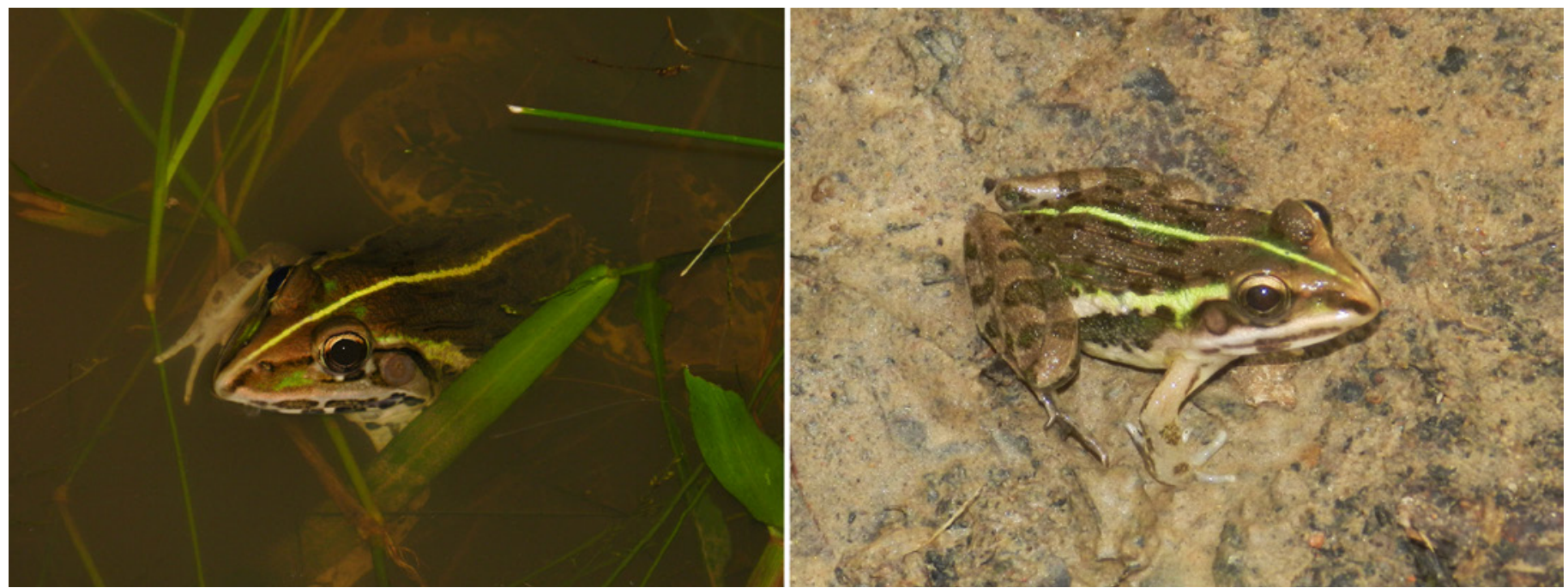

Fig. 3. Indian Bullfrog (Hoplobatrachus tigerinus). Photographs by Konok Roy.

many individuals. The species is not considered threatened in Bangladesh but is becoming increasingly rare in the Chittagong Hills due to heavy exploitation for food (Kabir 2009).

\section{Skipper Frog, Euphlyctis cyanophlyctis (Fig. 4)}

These frogs were abundant in all lentic habitats (ponds, lake, and low, wet areas). We were careful to distinguish this species from E. kalasgramensis, which Howlader et al. (2015) recently described from Bangladesh. The new species has a white venter (versus spotted in E. cyanophlyctis) and relative finger lengths of $1=2<4<3$ (versus $4<2<1<3$ ).

\section{Terrestrial Frogs, Fejervarya spp. (Fig. 5)}

Frogs in the genus Fejervarya are characterized by the presence of a "Fejervarya line" on both sides of the belly and the absence of rictal glands at the mouth commissure (Borthakur 2007). Hasan et al. (2014) recently recorded nine species in the genus Fejervarya in Bangladesh. During our surveys at BNP, we iden- tified three of those species, but we encountered several additional frogs in the genus that we were unable to identify.

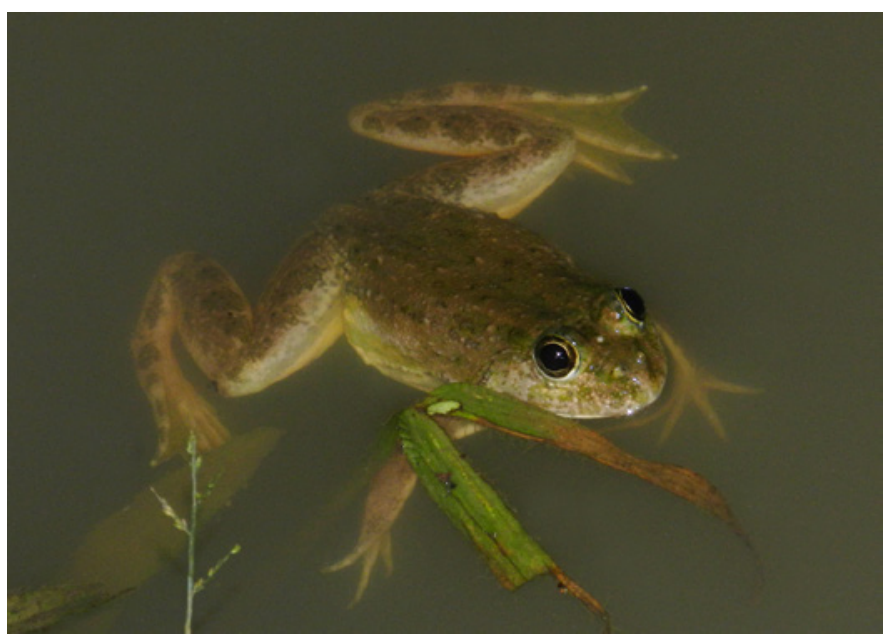

Fig. 4. Skipper Frog (Euphlyctis cyanophlyctis). Photograph by Ashim Mollik. 

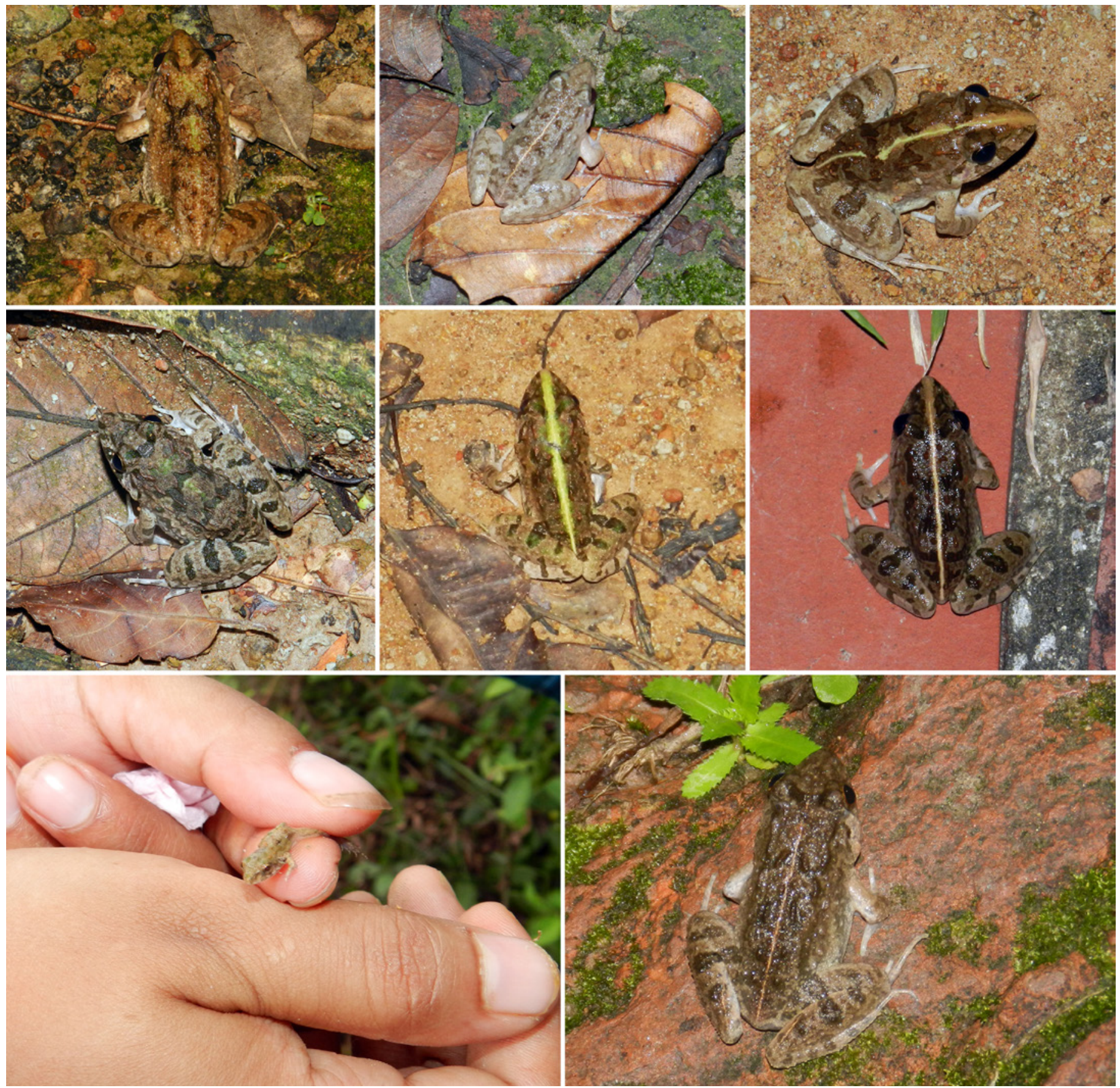

Fig. 5. Unidentified frogs in the genus Fejervarya. Photographs by Konok Roy and Ashim Mollik.

\section{Nepal Cricket Frog, Fejervarya nepalensis (Fig. 6)}

These small frogs were seen frequently on the forest floor, along forest edges, on the banks of the lake and ponds, and alongside agricultural plots. They often were under leaf litter, logs, or stones.

\section{Pierre's Cricket Frog, Fejervarya pierrei (Fig. 7)}

These small frogs also were abundant in BNP. Most individuals were in muddy patches on the forest floor and on the banks of bodies of water.
Crab-eating Frog, Fejervarya moodiei (Fig. 8)

These frogs probably belong to an undescribed species formerly assigned to F. cancrivora (e.g., Ahmad and Alam 2015, Chowdhury 2015). Usually associated with mangrove habitats, we found these frogs to be uncommon in marshy grasslands, on the forest floor, and along forest edges. Many individuals were under leaf litter, logs, or stones.

\section{Microhylidae}

Balloon Frog, Uperodon globulosus (Fig. 9)

We encountered a few of these frogs on the forest floor. 


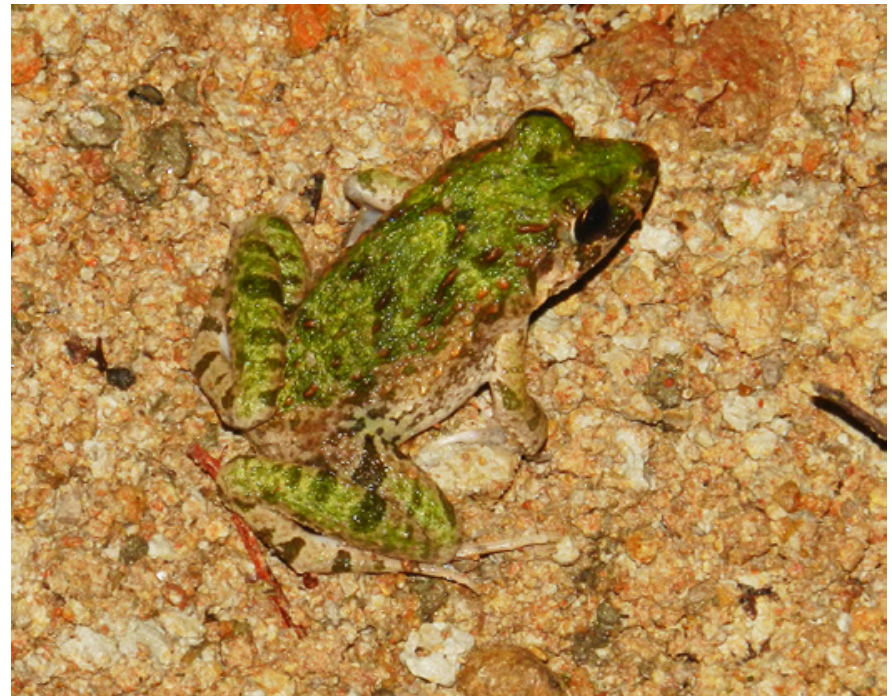

Fig. 6. Nepal Cricket Frog (Fejervarya nepalensis). Photograph by Konok Roy.

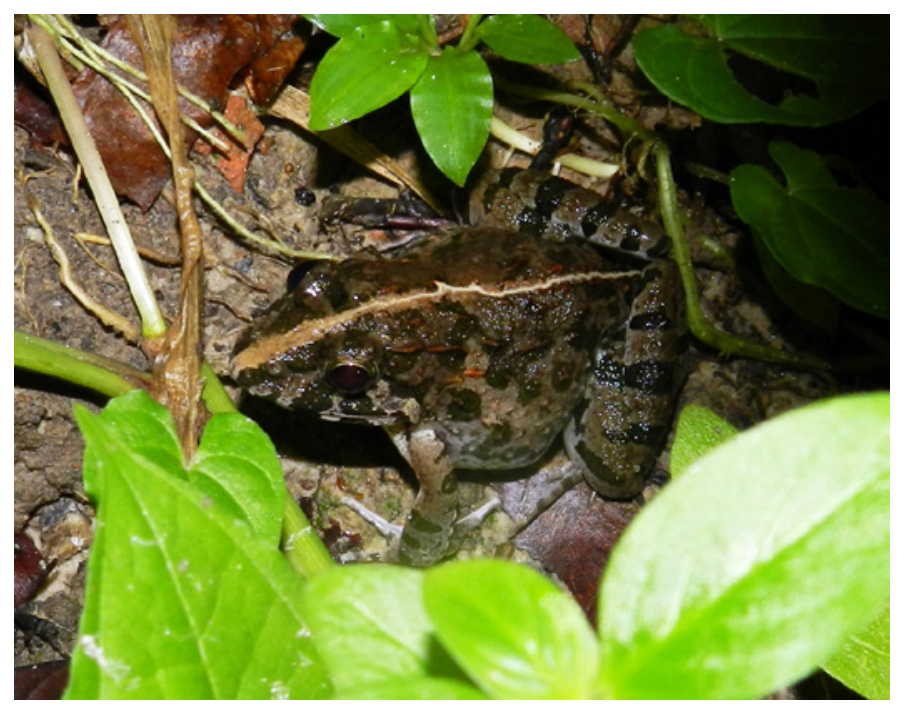

Fig. 7. Pierre's Cricket Frog (Fejervarya pierrei). Photograph by Konok Roy.

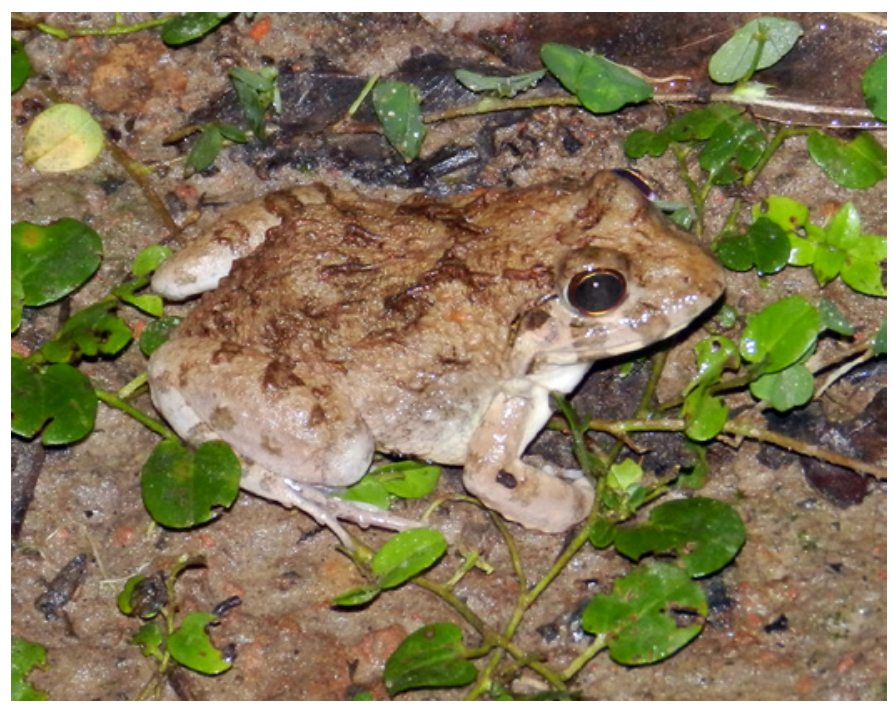

Fig. 8. Crab-eating Frog (Fejervarya moodiei). Photograph by Israt Jahan.

\section{Berdmore's Narrow-mouthed Frog, \\ Microhyla berdmorei (Fig. 10)}

These frogs were rarely encountered in BNP. We found a few individuals on the forest floor, along forest edges, and in rocky areas with vegetation.

\section{Ranidae}

Cope's Frog, Hydrophylax leptoglossa (Fig. 11)

We found these frogs active by both day and night in stagnant bodies of water with thick vegetation. Individuals were common in all lentic habitats.

\section{Rhacophoridae \\ Common Treefrog, Polypedates teraiensis (Fig. 12)}

This species was previously referred to Polypedates leucomystax (Kabir et al. 2009), which is now known to represent a complex of poorly known cryptic species (Hasan 2015). We found most individuals on trees at night. These frogs can leap great distances and the large toe pads allow them to cling to vertical surfaces.

\section{Discussion}

We found abundant suitable habitat for anurans in Bhawal National Park, but noted that the area is becoming increasingly altered due to anthropogenic activities. We found few or no frogs in agricultural plots and gardens, which might be attributable to the abundant use of insecticides (which cause declines in prey populations and might directly affect frogs). Visitors often throw waste materials (plastic bottles and polythene bags) into wetlands, disturbing frogs and reducing their ability to move freely through the water. Forest officials and local people sometime remove fallen logs that provide refugia for many species. The expansion of agriculture (encroachment of food and cash crops as well as timber plantations that reduce the biodiversity of the forest) are likely to result in future declines of anuran populations in BNP. To safeguard existing wild species, the park should be considered a high priority for conservation efforts, and detailed studies on the effects of anthropogenic activities are essential for developing management plans for the park.

\section{Acknowledgements}

We are very grateful to the Bangladesh Forest Department, with special thanks to Dr. Tapan Kumar Dey, Conservator of Forests, Wildlife and Nature Conservation Circle, and Mr. Shahab Uddin, DFO, Wildlife Management and Nature Conservation Division, Dhaka. We also thank Dr. Abhijit Das, Wildlife Institute of India, for valuable comments on an earlier draft of this manuscript. Shamima Begum Shewli, RIMS Unit, Research Officer, Bangladesh Forest Department provided the map of Bhawal National Park. Md. Anisur Rahman, Wildlife Supervisor, Gazipur Safari Park, and 

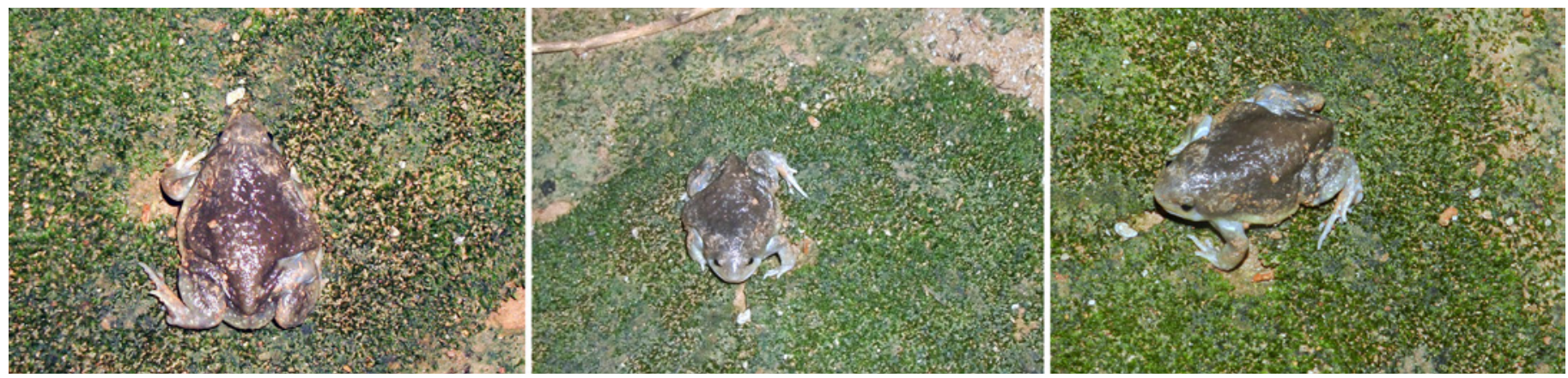

Fig. 9. Balloon Frog (Uporodon globulosus). Photographs by Konok Roy.

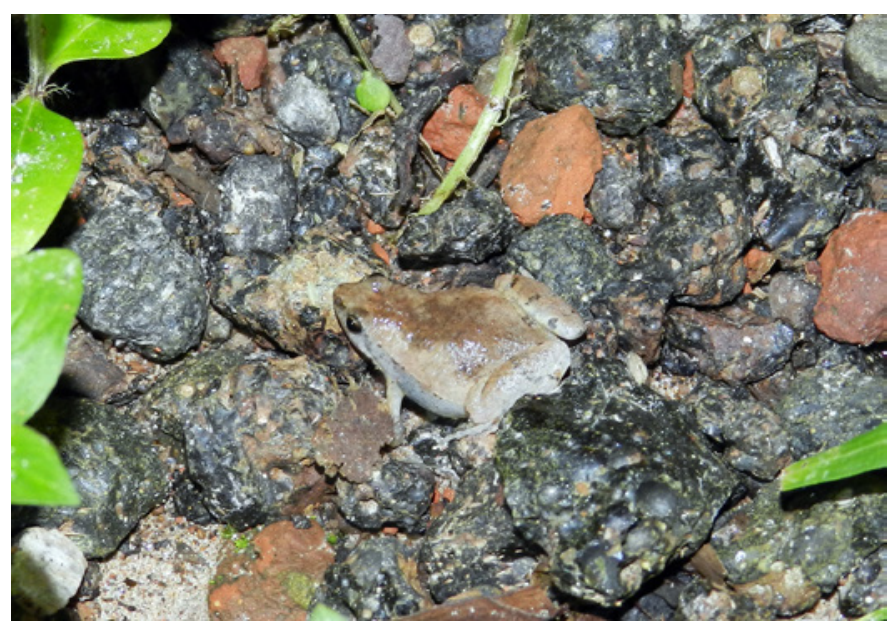

Fig. 10. Berdmore's Narrow-mouthed Frog (Microhyla berdmorei). Photograph by Konok Roy.

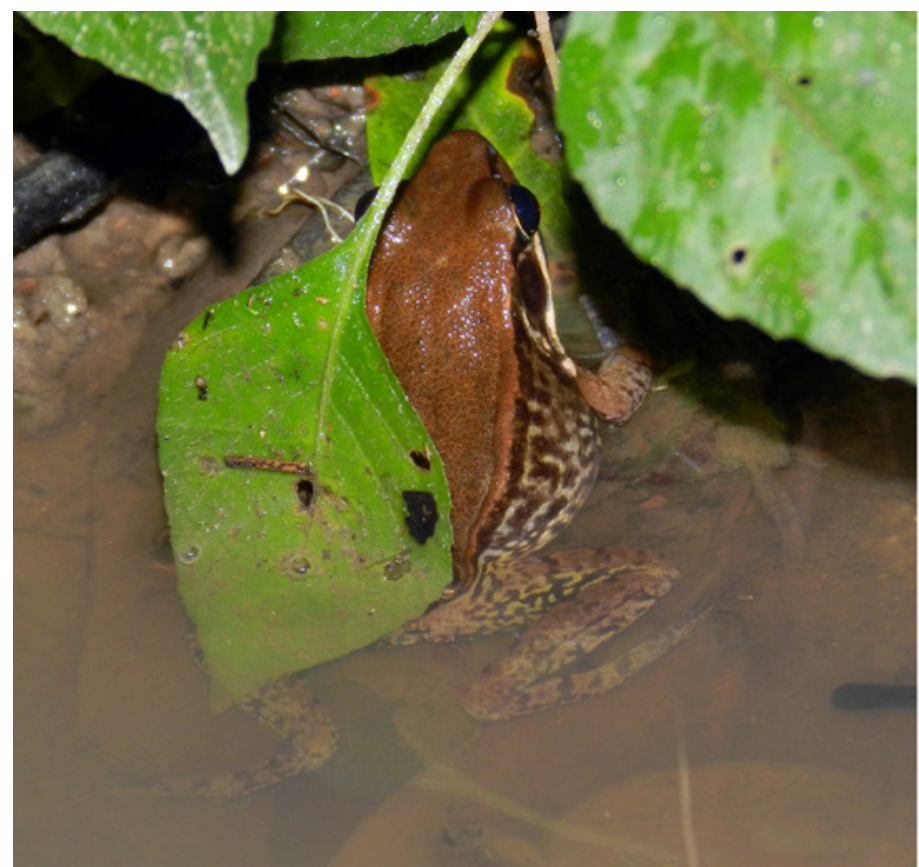

Mostafizur Rahman Tansen and Foysal Ahmed Peash, members of the Bangladesh Bird Club, helped in the field.

\section{Literature Cited}

Ahmad, F. and S.M.I. Alam. 2015. Frogs in the genus Fejervarya (Anura: Dicroglossidae) of the Nazipur Area, Patnitala Upazila, Naogaon District in northwestern Bangladesh. Reptiles \& Amphibians 22: 145-149.

Ahmed, M.F., A. Das, and S.K. Dutta. 2009. Amphibians and Reptiles of Northeast India: A Photographic Guide. Aaranyak, Assam, India.

Borthakur, R., J. Klita, B. Hussain, and S. Sengupta. 2007. Study on the Fejervarya (Anura: Dicroglossidae) species of Assam. Zoos' Print Journal 22: 2639-2643.

Bossuyt, F. and A. Dubois. 2001. A review of the frog genus Philautus Gistel, 1848 (Amphibia, Anura, Ranidae, Rhacophorinae). Zeylanica 6: 1-122.

Chanda, S.K. 2002. Hand Book Indian Amphibians. Zoological Survey of India, Kolkata.

Chowdhury, M.A.W. 2015. Fejervarya cancrivora. p. 249. In: IUCN Bangladesh, Red List of Bangladesh Volume 4: Reptiles and Amphibians. IUCN (International Union for Conservation of Nature), Bangladesh Country Office, Dhaka, Bangladesh.

Fig. 11. Cope's Frog (Hydrophylax leptoglossa). Photographs by Ashim Mollik.

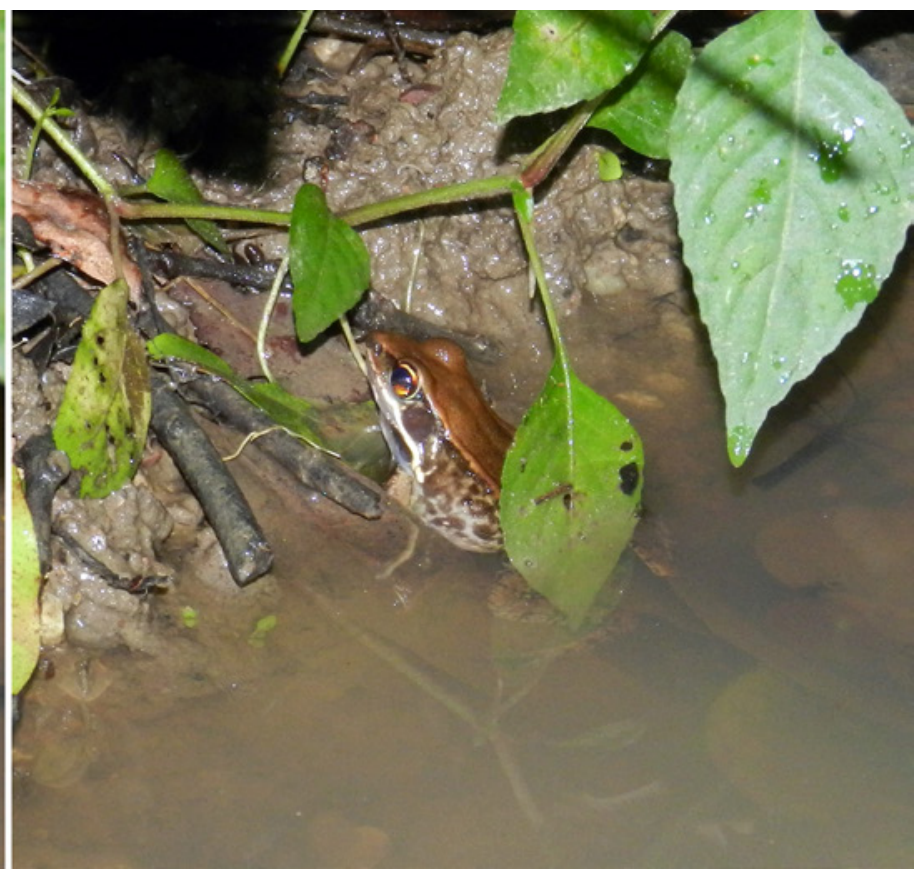



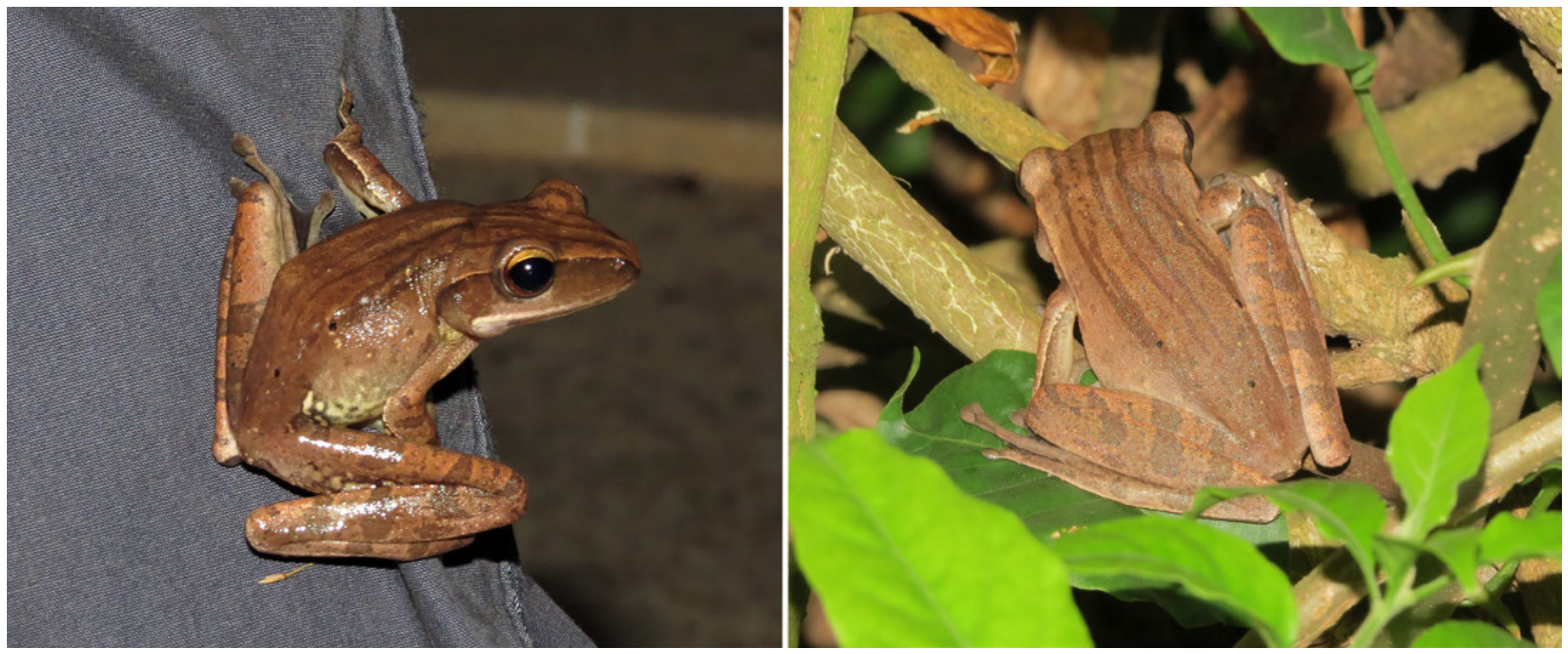

Fig. 12. Common Treefrog (Polypedates teraiensis). Photographs by Israt Jahan.

Dubois, A. 1975. Un nouveau complexe d'espèces jumelles distinguées par le chant: les grenouilles du Nepal voisines de Rana limnocharis Boei (Amphibiens, Anoures). Comptes Rendus Academy of Science Paris (D) 281: 1717-1720.

Dutta, S.K. and K. Manamendra-Arachchi. 1996. The Amphibian Fauna of Sri Lanka. Wildlife Heritage Trust of Sri Lanka, Colombo.

Das, A. 2008. Diversity and distribution of herpetofauna and evaluation of conservation status in Barail Herpetofauna Pproject, Final Report-March 2011. Conservation status in Barail Hill Range (including Barail Wildlife Sanctuary), Assam, Northeast India. Aaranyak, Guwahati, Assam, India.

Frost, D.R. 2015. Amphibian Species of the World: An Online Reference. Version 6.0. American Museum of Natural History, New York (http://research.amnh.org/ herpetology/amphibian/index/html).

Hasan, E. and K.M. Bahauddin. 2014. Community's perception and involvement in co-management of Bhawal National Park, Bangladesh. Journal of Natural Sciences Research 4: 60-67.

Hasan, M.K., M.M.H. Khan, and M.M. Feeroz. 2014. Amphibians and Reptiles of Bangladesh — A Field Guide. Arannayk Foundation, Dhaka, Bangladesh.

Hasan, M.K. and M.M. Feeroz. 2014. Species diversity and habitat preferences of amphibian fauna in six protected areas of Bangladesh. Bangladesh Journal of Zoology 42: 105-116.

Hasan, M.K. 2015. Polypedates leucomystax, p. 264. In: IUCN Bangladesh, Red List of Bangladesh Volume 4: Reptiles and Amphibians. IUCN (International Union for Conservation of Nature), Bangladesh Country Office, Dhaka, Bangladesh.

Hasan, M., M.M. Islam, M.M.R. Khan, M.S. Alam, A. Kurabayashi, T. Igawa, M. Kuramoto, and M. Sumida. 2012. Cryptic anuran biodiversity in Bangladesh revealed by mitochondrial 16S rRNA gene sequences. Zoological Science 29: $162-172$.

Hocking, D.J. and K.J. Babbitt. 2014. Amphibian contributions to ecosystem services. Herpetological Conservation and Biology 9: 1-17.

Hall, R.J. and P.F.P. Henry. 1992. Assessing effects of pesticides on amphibians and reptiles: Status and needs. Herpetological Journal 2: 65-71.

Howlader M.S.A., A. Nair, S.V. Gopalan, and J. Merilä. 2015. A new species of Euphlyctis (Anura: Dicroglossidae) from Barisal, Bangladesh. PLoS ONE 10(2): e0116666.
IUCN Bangladesh. 2015. Red List of Bangladesh Volume 4: Reptiles and Amphibians. IUCN (International Union for Conservation of Nature), Bangladesh Country Office, Dhaka, Bangladesh.

Kabir, D.S. and A.Z. Ahmed. 2005. Wildlife biodiversity in Bhawal National Park: Management techniques and drawbacks of wildlife management and nature conservation. Our Nature 3: 83-90.

Kabir, S.M.H., M. Ahmed, A.T.A. Ahmed, A.K.A. Rahman, Z.U. Ahmed, Z.N.T. Begum, M.A. Hassan, and M. Khondoker (eds.). 2009. Encyclopedia of Flora and Fauna of Bangladesh, Vol. 25: Amphibians and Reptiles. Asiatic Society of Bangladesh, Dhaka.

Kurniawan N., T.H. Djong, M.M. Islam, T. Nishizawa, M.B.Daicus, H.S.Yong, R. Wanichanon, I. Yasir, and M. Sumida. 2011. Taxonomic status of three types of Fejervarya cancrivora from Indonesia and other Asian countries based on morphological observations and crossing experiments. Zoological Science 28: 12-24.

Myers, N., R.A. Mittermeier, C.G. Mittermeier, G.A.B. da Fonseca, and J. Kent. 2000. Biodiversity hotspots for conservation priorities. Nature 403: 853-858.

Rahman, M.M. and H. Vacik. 2009. Can picnic influence floral diversity and vitality of trees in Bhawal National Park of Bangladesh? Forestry Studies in China 11: $148-157$.

Stanford, C.B. 1991. The Capped Langur in Bangladesh: Behavioral Ecology and Reproductive Tactics. Contributions to Primatology, Volume 26. Karger Publishers, Basel, Switzerland.

Sarker, N.M. and A.K.M. Fazlul Huq. 1985. Country report on national parks, wildlife sanctuaries and game reserves of Bangladesh. Prepared for the 25th Working Session of IUCN's Commission on National Parks and Protected Areas. Corbett National Park, India.

Stuart, S., J.S. Chanson, N.A. Cox, B.E. Young, A.S.L. Rodrigues, D.L. Fishman, and R.W. Waller. 2004. Status and trends of amphibian declines and extinctions worldwide. Science 306: 1783-1786.

Stuart, S.N., M. Hoffmann, J.S. Chanson, N.A. Cox, R.J. Berridge, P. Ramani, and B.E. Young (eds.). 2008. Threatened Amphibians of the World. Lynx Edicions, Barcelona, Spain; IUCN, Gland, Switzerland; and Conservation International, Arlington, Virginia, USA. 